\title{
UN CAZ DE RETRACTIIE DE CVADRICEPS LA COPIL: ETIOLOGIE, DIAGNOSTIC, PROFILAXIE
}

\author{
Dr. Bauer Adalbert, medic primar pediatru, doctor în medicină
}

\section{Rezumat}

Practica pediatrică contemporană, cu toate cuceririle moderne, nu este scutită de anumite inconveniente iatrogene, legate de diferitele procedee terapeutice, acestea din nefericire cu urmări şi sechele, în unele cazuri infirmizante. Problema pusă în discuție se poate analiza sub aspectul competenței profesionale, de etică şi de ontologie medicală, iar în cazuri rare şi cu implicaţii legale.

$\mathrm{O}$ astfel de situație este retracția de quadriceps cu modificări sechelare statice şi funcționale.

Autorul prezintă 5 cazuri, cu scopul sensibilizării practicienilor, în vederea prevenirii acestor afecțiuni infirmizante.

Administrarea de injecții intramusculare copiilor imaturi, gemeni, noi-născuți, distrofici cu grade avansate de distrofie, sau chiar sugarilor eutrofici, care părea în urmă cu 8-10 ani a fi un procedeu simplu, fără riscuri, astăzi s-a dovedit în unele împrejurări dăunătoare, prin producerea unor leziuni anatomice loco-regionale care se repercută asupra funcțiilor statice sau motorii al copilului în diferite etape ale creşterii.

DISCUȚII: Problematica clinică a retracției de quadriceps după injecții intramusculare apare în literatură cu 30-40 de ani în urmă, primele comunicări aparținând lui BIGAN (1964)-GAMMIE (1963), GUN (1964), MALEK (1966), chirurgia infantilă sesizând importanța practică a problemei fundamentând metode sau tehnici adecvate pentru recuperarea deficiențelor motorii. Astfel PETIT (1967), RIGAULT (1967), POULIQUEN (1972) au publicat lucrări statistice asupra cazurilor operate, cu rezultate convingătoare.

Cercetând literatura de specialitate se poate concluziona că retracția quadricepsului din nefericire nu este o afecțiune foarte rară. Depistarea insuficientă sau tardivă se datorează faptului că medicii chirurgi şi neurologi, dar mai ales pediatrii nu sunt sensibilizați în suficientă măsură cu problemele clinice ale afecțiunii, nici chiar în zilele noastre.

Copilul suferind pendulează între aceste servicii de specialitate, fără a fi elucidat cadrul nosologic care stă la baza tulburărilor statice sau motorii ale copilului. În unele cazuri părinții trăiesc emoțiile unor diagnostice mai mult sau mai puțin sumbre, stabilite de specialişti pediatri, chirurgi, neuro-psihiatrii ca: encefalopatie cronică infantilă cu retardare motorie, anomalii ale sistemului osteo-articular, miopatii, dismorfisme genetice de diferite feluri, etc.

Ținând cont de importanța practică a problemei şi având în decursul anilor 5-6 cazuri în observație, cu diferite grade de suferință din care 2 cazuri soluționate chirurgical-ortopedic (intervenții paliative) în cele ce urmează îl prezint pe cel mai instructiv.

\section{Prezentarea cazului}

Copilul S.I. în vârsta de 5 ani, din municipiul Satu-Mare, a fost adus la serviciul nostru, pentru un deficit motor segmentar localizat la nivelul membrului inferior stâng, care s-a instalat în urmă cu 3 ani şi care de la apariția primelor semne de suferință, s-a accentuat treptat, prezentând în momentul examinării următoarele modificări anatomo-funcționale: 
- o hipotrofie a musculaturii coapsei stângi, perimetrul coapsei fiind mai redus $\mathrm{cu} 1,5 \mathrm{~cm}$ decât cel sănătos.

- o contractură cu flexiune permanentă a membrului inferior stâng, de aproximativ 20 de grade.

- piciorul stâng rotat uşor înăuntru, mers legănat cu şchiopătare intermitentă.

- pe fața exterioară a coapsei stângi se pune în evidență o pată de mărime 2 x2,5cm, foarte fin depigmentată, uşor deprimată şi aderentă planurilor profunde.

- pielea aderentă se mişcă simultan cu contracțiile musculaturii subiacente.

- deprimarea regiunii respective a devenit şi mai pronunțată în pozițiile de flexie şi abducție precum şi prin mişcări active de rotaţie a coapsei.

Cercetarea neurologică, radiologică şi chirurgicală a segmentelor motorii interesate s-a efectuat de specialişti care nu au semnalat modificări semnificative.

Din antecedentele personale a copilului reiese că a fost născut cu 1800 grame, care în toată perioada neonatală a fost internat în spital, suferind o infecție stafilococică sistemică cu localizare pluriviscerală, pentru care a urmat tratamente parenterale numeroase şi repetate, bineînțeles şi injecții intramusculare într-un număr impresionant. Mama copilului afirmă că în două rânduri în decurs de o lună de internare, coapsa stâng a copilului a fost tumefiată din cauza numeroaselor injecții intramusculare şi s-a aplicat comprese locale cu scop antiinflamator.

Prezentând un fond de diateză limfatică, un teren somatic şi imunologic compromis din perioada neonatală, ulterior cu infecții repetate a căilor respiratorii superioare, după afirmația mamei copilul până la vârsta de 2 ani mai face în jur de 250 de injecții în coapse, agravând cu multă probabilitate leziunile anatomice preexistente.

Din antecedente lipsesc alte cauze care ar putea servi ca factor etiologic al retracției ca: traumatisme, infecții, imobilizări îndelungate, boli generale ca artrogripoza, mucopolizaharidoze, sindroame genetice, etc. Examinările paraclinice biologice nu au prezentat modificări. Radiografia articulației genunchiului pune în evidență doar o contractură de flexiune, în rest nimic patologic. Electromiografia şi biopsia musculară nu s-au putut efectua, oricum ele nu furnizează în toate cazurile rezultate apreciabile.

Diagnosticul pozitiv s-a bazat pe datele anamnestice concludente şi pe modificările morfo-funcționale locale specifice afecțiunii.

În decursul anilor în afară de acest caz reprezentativ am mai întâlnit un număr de 4 cazuri cu manifestări clinice variabile, fie cu tulburi de mers la o fetiță de 2 ani, fie scăderea forței musculare, oboseală cu întreruperea activităților, cu diminuarea perimetrului coapsei afectate, sau modificări locale a tegumentelor coapsei - un semn clinic de atenționare a practicianului pediatru. Apariția simptomatologiei chiar minore sau mai subtile durează între 2-5 ani.

\section{Etiologia-patogenia}

POLIUQUEN evocă la baza retracției tratamente injectabile efectuate la vârsta de nou-născut, imaturi, gemeni, subponderali, distrofii avansate în primele 5-6 luni, sugari reanimați, în general la cei cu spitalizare prelungită.

La acest grup de copii, dar mai ales la imaturi, țesutul muscular este foarte slab dezvoltat. După unii autori masa musculară raportată la greutatea corporală a imaturului este mai mică cu până la 40 \% decât cei născuți la termen. Pe lângă acest deficit procentual privind volumul masei musculare şi elementele celulare funcționale prezintă o imaturitate evidentă (SURANYI).

Traumatismele repetate produse prin injecții intramusculare, cu leziuni consecutive a vaselor musculare şi formarea de hematoame, servesc ca bază fiziopatologică în transformarea fibroasă a parenchimului muscular (SEE-BRIARD). Participarea unui proces infecțios agravează în mod substanțial procesul de scleroză (DUFEK). Proprietățile farmaco-dinamice a injecțiilor nu par să aibă un loc pri- 
mordial în provocarea leziunilor, dar rămâne totuşi un capitol deschis sub aspectul studiului fiziopatologic al afecțiunii. Raritatea relativă a cazurilor semnalate poate evoca o eventuală fragilitate particulară a musculaturii subiecților. Prezența afecțiunii la gemeni monozigoți după unii ridică ipoteza unor influențe genetice (MASSE).

Leziunile anatomice au fost studiate grație intervențiilor chirurgicale şi biopsiile musculare care pun în evidență un proces de fibroză format din țesut conjunctiv în zonele musculare afectate.

\section{Studiul clinic}

Studiul antecedentelor neonatale prezintă o importanță deosebită. CHAPUIS afirmă că în unele cazuri se desfăşoară o adevărată anchetă polițistă în vederea stabilirii unor intimități privind aprecierea tratamentelor aplicate sau existența unui abces al coapsei.

Un interogatoriu minuțios al părinților, o cercetare a mediului obstetrical sau spitalicesc, inclusiv şi foaia de observaţie în vederea reconstituirii istoricului afecțiunii neonatale şi a tratamentelor injectabile aplicate, sînt elemente de bază a precizării diagnosticului pozitiv.

Dintre argumentele clinice aş evoca leziunea specifică caracteristică, - o pată foarte fină, depigmentată, pe fața anterioară a coapsei, care se observă mai greu la copii blonzi, cu tegumente mai slab pigmentate. Deprimarea şi aderarea planurilor subiacente a pielii este considerată ca un semn specific pentru abcese cu scleroză consecutivă. Deplasarea simultană a pielii cu contracțiile quadricepsului evocă în mod fidel aderența şi scleroza musculaturii.

Valoarea examenului electromiografic este discutabilă. În cazurile când antecedentele şi semnele clinice sînt necaracteristice, el arată zone de inactivitate musculară în cadrul teritoriului sclerozat.

Biopsia musculară confirmă scleroza vastului extern sau a celui intern, dar în multe cazuri rămâne negativă, contrar tabloului clinic evident.

Din punct de vedere clinic retracția se poate prezenta sub două forme:

1) O retracție simplă a genunchiului, cu localizare uni sau bilaterală. Aceasta se consideră a fi forma cea mai frecventă şi se rezumă la o limitare moderată a mişcărilor de flexie.

Precizarea vârstei la care se manifestă retracția de multe ori prezintă dificultăți. În majoritatea cazurilor ea are aparența unei anomalii congenitale. $2 / 3$ din cazuri debutează înaintea vârstei de 6 ani, dar depistarea primelor semne clinice poate fi făcută între 2-4 ani. Se consideră o problemă dificilă precizarea rapidității retracției. HNEVKOVSKY stabileşte un ritm anual de 10-20 de grade, dar trebuie subliniat că aceste cifre sunt variabile de la autor la autor. În cazuri mai grave retracția este mai severă, cu limitarea de până la 40 de grade. Blocajul mişcărilor de flexiune este net, brutal, cu senzație de obstacol mecanic (CHAPUIS). Retracția nu este dureroasă şi nu limitează extensia activă.

2) Luxație sau subluxație de rotulă prin contractura genunchiului. Aceste forme sunt foarte rare şi apar la vârste mai tardive, în general între 7-10 ani. POULIQUEN descrie un singur caz sub vârsta de 4 ani. Acest fapt se consideră important pentru că sugerează originea câştigată a acestei luxaţii habituale care persistă de la naştere.

Cazurile uşoare de retacție se pot trata medical prin masaje, mobilizare pasivă prudentă, urmată de mobilizare activă.

Cazurile mai grave, cu o participare evidentă de ordin mecanic reclamă soluții chirurgicale. Intervenția chirurgicală cu desinserția grupului muscular sclerozat şi reimplantarea în poziții mai joase, urmată de imobilizare de câteva zile şi readucerea pasivă şi activă îndelungată (tehnica lui JUDET). Rezultatele globale ale intervențiilor chirurgicale sunt bune. 


\section{Concluzii}

1) Potențialul anatomo-funcțional diminuat al țesutului muscular la categoria copiilor periclitați (imaturi, gemeni, născuți subponderal, reanimați, distrofii avansate) ne obligă să schimbăm optica privind tratamentul injectabil în vederea evitării unor complicații iatrogene.

2) Luând în considerare gravitatea perturbărilor statice şi motorii, în multe cazuri infirmizante, produse de retracția quadricepsului, se impune o profilaxie prin raționalizarea tratamentului la toate nivelurile din asistența copilului.

3) Profilaxia retracției se poate realiza prin următoarele obiective:

- respectarea riguroasă a măsurilor de asepsie şi a tehnicii de administrare a injecţiilor,

- prescrierea cu mult discernământ a tratamentelor injectabile,

- schimbarea anatomo-topografică a locului injecțiilor intramusculare,

- în afecțiunile grave este recomandabilă administrarea medicamentelor pe cale endovenoasă, iar în cele uşoare pe cale bucală

- evitarea administrării substanțelor farmaco-dinamice cu efect sclerozant.

4) Prin depistarea precoce a afecțiunii se poate opri progresiunea procesului de fibrozare, precum şi contractura consecutivă, care conform datelor din literatură atinge un ritm anual de 10-15 grade.

5) Odată depistat, subiectul trebuie îndrumat la un serviciu de Ortopedie Infantilă, pentru remedierea medicală sau chirurgicală a modificărilor morfo-funcționale prin intervenție paliativă.

6) Administrarea tratamentelor parenterale într-un țesut sclerozat la categoria copiilor mai sus amintiți, pe lângă că este ineficientă, face ca practicianul să trăiască cu falsa impresie şi conştiința că atitudinea lui terapeutică a fost corectă. Din nefericire necunoaşterea acestui fapt poate avea consecințe dramatice pentru copil.

\section{Bibliografie}

1. Pouliquen J.P., Rigault J.J., Chapuis B. Annale de Pediatrie 1972; 8: 2361-2368.

2. Petit P., Malek R. Communication au Congres de la Société Francaise De Ortopedie 1985.

3. Suranyi Gy. A koraszülött. Budapest: Editura Medicală.

4. See G., Briard I. Annales de pediatrie 1978; 8: 360-366.

5. Masse P., Pouzol I. Archives francaise de Pediatrie 22: 597-705.

6. Masse P., Pujol I., Bigan R. Archives francaise de Pediatrie 7: 886-887. 